\title{
The Philosophical Values of Kawung Batik Motif in Contemporary Batik Painting
}

\author{
Adam Wahida ${ }^{1}$, Endang Sri Handayani ${ }^{2}$, dan Slamet Supriyadi ${ }^{3}$ \\ Pendidikan Seni Rupa, FKIP, Universitas Sebelas Maret, Surakarta, Indonesia
}

adamwahida@staff.uns.com

Sebagai salah satu batik klasik Jawa, motif batik Kawung mengandung nilai-nilai filosofis yang mengajarkan pedoman kehidupan bagi manusia, seperti rasa syukur, religiusitas, penghormatan terhadap alam, dan kebersamaan. Nilai-nilai filosofis tersebut masih relevan dengan situasi saat ini, sehingga menarik untuk dijadikan sebagai sumber ide penciptaan karya seni lukis kontemporer. Artikel ini merupakan hasil penelitian yang bertujuan untuk mendiskripsikan nilai-nilai filosofis motif batik Kawung sebagai sumber ide dan proses penciptaan seni lukis batik kontemporer. Metodenya deskriptif kualitatif dengan jenis penelitian penciptaan seni. Adapun tahapannya meliputi: 1) mengumpulkan informasi tentang motif batik Kawung, 2) mengeksplorasi ide-ide berdasarkan makna filosofis dari motif batik Kawung, 3) membuat sketsa rancangan, 4) mewujudkan sketsa ke dalam lukisan, 5) mendeskripsikan bentuk karya seni lukis yang diciptakan. Hasil penelitian ini adalah: 1) deskripsi tentang makna filosofis motif batik Kawung, 2) deskripsi tentang proses penciptaan karya seni lukis batik kontemporer, 3) deskripsi bentuk karya seni lukis batik kontemporer yang mengandung nilai-nilai filosofis motif batik Kawung. Hasil penelitian ini menunjukkan bahwa karya seni lukis batik yang dihasilkan memiliki karakter lokal dan mewakili jiwa zaman. Dengan demikian, terbukti bahwa nilai-nilai kearifan lokal budaya tradisional dapat dikembangkan dan diselaraskan dengan budaya kontemporer.

Kata kunci : filosofis, motif batik kawung, seni lukis batik kontemporer

As one of the classic Javanese batik, the Kawung batik motif contains philosophical values that teach life guidelines for humans, such as gratitude, religiosity, respect for nature, and togetherness. These philosophical values are still relevant to the current situation, so it is interesting to be used as a source of ideas for the creation of contemporary paintings. This article is the result of research that aims to describe the philosophical values of the Kawung batik motif as a source of ideas and the process of creating contemporary batik paintings. The method is descriptive qualitative with the type of art creation research. The stages include: 1) gathering information about the Kawung batik motif, 2) exploring ideas based on the philosophical meaning of the Kawung batik motif, 3) making a design sketch, 4) realizing the sketch into a painting, 5) describing the shape of the painting created. The results of this study are 1) a description of the philosophical meaning of Kawung batik motifs, 2) a description of the process of creating contemporary batik painting works, 3 ) a description of the forms of contemporary batik painting works that contain philosophical values of Kawung batik motifs. The results of this study indicate that the batik painting produced has a local character and represents the soul of the times. Thus, it is evident that the local wisdom values of traditional culture can be developed and harmonized with contemporary culture.

Keywords : philosophical, kawung batik motif, contemporary batik painting

Proses Review : 1 - 28 Januari 2020, Dinyatakan Lolos: 10 Februari 2020 


\section{INTRODUCTION}

Kawung is one type of classical Javanese batik motif whose existence is still actualized by the community in various important daily events or traditional ritual ceremonies. In the Kawung classic batik motif contained philosophical values about the teaching of goodness; so that someone has an awareness of living together and providing mutual benefits for others. These values include gratitude, religiosity, respect for nature, and togetherness.

The basic form of Kawung batik motifs consists of elliptical geometric ornaments arranged diagonally to form a cross with repetitive composition patterns. The basic color of the Kawung batik motif is a combination of dark and bright colors. In the perspective of ancient Javanese culture, color is a symbol or character of the human being symbolized by Panca Warna or five colors (Sewan Susanto, 1984: 91). The colors red, black, yellow, green, and white are symbols of lust, namely: Amarah, Aluwamah, Supiah, and Muthmainah. This whole series of five colors symbolizes the basis of human nature which leads to lust for anger. Even so, if humans can control these desires it will instead bring forth good strength, noble character, and wisdom.

The Kawung batik motif as a classic batik, based on its appearance, meaning, and function, is conceptually inseparable from the Javanese mindset which views humans in the context of harmony with an orderly, harmonious and balanced universe. It gave birth to symbolic expressions in forms that tend to be subtle, static but magical in their patterns and color. Therefore, Kawung batik motifs are not merely ornamental on fabric, but also indigenous knowledge that penetrates philosophical areas in the form of moral didactives guides the conception of life to those related to spirituality as indigenous philosophy achievements (Budi, 2017: 32).

The philosophical values in the Kawung batik motif are still relevant to be used as guidelines and philosophies in today's life. Therefore, it can be used as inspiration, developed, and embodied in the idea of creating contemporary art following the soul of the era. Contemporary art discourse is a breakthrough of new enthusiasm in art life that is often referred to as the era of the celebration of the awareness of differences, where the appreciation of the principles of pluralism and multiculturalism began to be a concern. Therefore, various strategic issues of arts within the framework of this contemporary, find a very conducive space. Including the excavation of traditional cultural values as a source of art development (Kasiyan, 2009: 164). Traditional or classical works of art as local wisdom have a strategic position which is a force to resist the influence of outside cultures. but it can also be developed for the future of the nation's culture. Therefore it is important to make an effort to fertilize and develop the values of local wisdom so that it functions for people's lives, both in lifestyle, life attitudes, perceptions, and life orientation (Poespowardojo, 1986). Thus, the community as the heir to the traditional culture can show its dedication to building a cultural life that is in harmony with the changing times.

In summary, the research problems that can be formulated in the study of the creation of contemporary batik painting works include the concept of visual aesthetics, the process of creation, and the visual meaning of the resulting artwork. The series of studies, creations, and presentations of the works were carried out to achieve the objectives, which included the disclosure of the philosophical values of the Kawung batik motif as a source of ideas for the creation of contemporary batik paintings, finding approaches/ methods of art creation, and formulating the meaning of the works.

\section{METHOD}

Peter Dallow (2003: 51) states that there are several efforts to formulate and expand research approaches to creative arts that are specifically focused on the practice of art creation. This generally views creative arts research as qualitative research which does not, usually, begin with a set of questions or assumptions that have been determined but arise from the particular situation or context being investigated (Frayling, 1997: 22). Margolin (1998) in Peter Dallow (2003: 52) describes a research approach through art and design, which is centered on a 'studio project', representing a new 'practice' approach to research that is not bound by traditional methodology but seeks to 'facilitate a reflection relationship with practice '(1998: 98).

This method uses a research approach based on art practice, with stages; 1) collecting data and information on themes, philosophical meanings and aesthetic of Kawung batik motifs. Data and information that have been collected are then validated through source triangulation, peer debriefing, rechecking. Then analyzed with interactive models (interactive of model analysis) including data reduction, data presentation, verification/conclusion drawing. 2) exploring ideas based on the philosophical and aesthetic meanings of Kawung batik, 3) developing sketches or designs that are realized through the selection of visual symbols based on philosophical ideas., 4) creating paintings, through painting on fabric approaches 5) analyzing the resulting artwork.

\section{RESULTS AND DISCUSSION}

\section{Forms and Philosophical Meanings of Kawung Batik} Motif

Based on the Iconographical Analysis theory from Erwin Panofsky (1982:7-14), the steps to interpret classical batik motifs can be done through three stages that are prerequisite, namely: (1) primary or natural subject matter, 
(2) secondary or conventional subject matter, (3) intrinsic meaning or content. At the primary or natural subject matter stage, the process of analysis is based on factual and expressional aspects of visual forms which are ideal of real and expressive realities based on captured impressions, between these signs and an event that occurs with their creation. This process is also called a pre-iconographical description. Furthermore, the secondary or conventional subject matter stage is the process of identifying secondary meanings through the description of visual signs from the analysis results of the pre-iconographical description to explore the relationship between themes and concepts of the work. This process is called formal analysis or iconographical analysis, which deals with the world of images, stories, allegories, and ideas and goals of creation. While the last stage, intrinsic meaning or content, is the interpretation stage of intrinsic meaning or the content of artwork based on the pre-iconography and iconographic analysis. This process is called iconological interpretation, which is a method of interpretation that relies more on the 'intuition of synthesis' which is nuanced to the 'essential tendencies' of the human mind and cultural domain. The implementation is the cultural context of the Surakarta and Javanese communities; which refers to the indication 'symbolic behavior'.

Kawung is a classic batik motif that visually consists of geometric shapes of oval or ellipse spheres, arranged in a diagonal repetition composition sloping left and right alternately with colors consisting of ocher, dark brown, and black. In the general view of society, Kawung's motives are considered to be inspired by the Kawung fruit seeds which are split into two so that four basins look into four corners. Historically, the Kawung motif was created by Sultan Agung Hanyokrokusumo in Mataram. He created by taking materials from nature, or simple things and then made into a good batik motif (Koeswadji, 1981: 112). In classical batik, Kawung motifs are included in the $\mathrm{Ce}$ plok type with changes in the circle to be rectangular or star-shaped, which are also arranged geometrically. This Ceplok pattern is related to Javanese belief in pre-Hindu times, namely Kejawen which is based on the concept of 'power' which is power in the universe and power between humans (Pramono, 2013: 141).

In the Kawung motif, it is reflected in the power of the King who is the center of power in the world, the weak human leader and the protector. The manifestation of the King's power in the batik motif can be seen in the center surrounded by four circular shapes. In Javanese belief, the four forms that surround the center are the source of energy of the universe, namely: a) The east is connected with the rising of the sun, the source of energy for all life, ) The South is associated with Zenith or the climax of everything, d) The North is the direction of death, the source of life-saving energy. The concept with a center of power surrounded by four sources is called Moncopat (Condro-

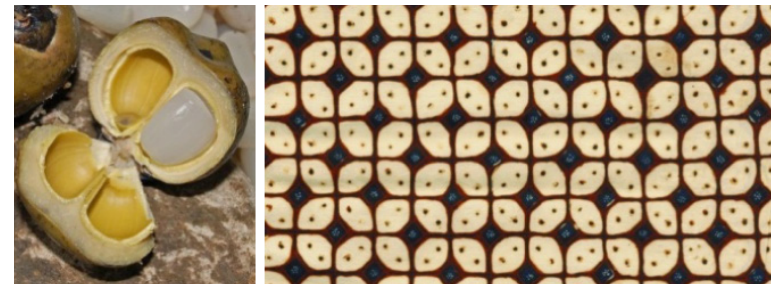

Figure 1. Kawung fruit (left) and kawung motif (right) negoro, 1995: 19).

Another perspective in Javanese cosmology, the basic Kawung motif is a symbol of the concept of Panca-Pat which always symbolizes the number of 4 (four) similar forms and one center or core. Panca-Pat is traditional wisdom in the philosophy of cosmology and life, state regulations, politics, and economics. The concept of Panca-Pat is described as follows: 1) Keblat Papat Lima Pancer, meaning that wherever it is called the four winds, always humans are in the middle of it. 2) Sedulur Papat Lima Pancer, is a traditional perspective of life, when a baby is born it will always be together with four twin siblings, namely red blood, amniotic fluid, placenta, and navel, which are believed to affect each other until a certain age. 3) In the kingdom of Mataram, the King was assisted by four advisors, namely in the fields of politics, economics, defense of security, technology, and spiritual. The palace as the center of government is divided into four regions, namely Kutanegara, Negaragung, Mancanegara, and Pesisiran. 4) Human behavior is the embodiment of four desires, namely Mutmainah, Amarah, Aluamah, and Supiah, where good desires (Mutmainah) are often in conflict with three other desires (Kushardjanti, 2008). "Keblat Papat Lima Pancer" as Javanese philosophy is related to the 'world of time', meaning the four-dimensional classification of space with a four-carded pattern with one center. This is related to human awareness of the inseparable relationship between himself and the universe. This concept states that basically humans are born with lust that comes from himself. Based on the five-point view of Qibla, lust which is the basis of human character can be divided into four according to the direction of the wind, namely Lauwamah, Supiyah, Amarah, and Mutmainah (Simuh, in Sony Kartika, 2007: 33). Of the four forms of human lust, only one has a noble character, namely Mutmainah, while the other three are negative characters. Even so, humans can still maintain their balance in certain ways. These four elements are the basis of a microcosm that can only be conquered by the ability of the human person himself.

Associated with the concept of "Keblat Papa Lima Pancer" which is related to the "world of time» and the end of the human journey in maintaining the balance of passion in the world, often batik motifs Kawung motifs are used as a ritual of death, which is as a Lurub or closing the body. This implies that the body can return to eternity smoothly. Kawung is intended as "Bali Nang Suwung" which means returning to the realm of Suwung, an empty ie af- 
terlife. Related to the word Suwung which means empty, the Kawung motive becomes a symbol of emptiness in lust and worldly desires; means perfect self-control. This emptiness makes a person in a neutral position, does not take sides, does not want to stand out, follow the flow of life, let everything around him go according to the will of nature. Thus, the Kawung motif in a broader understanding implies perfection and purity.

\section{Preliminary Form of Artwork Creation \\ a. Idea of Creation}

The idea of creating contemporary art with the batik painting on the fabric approach arises from the study of the philosophical and aesthetic significance of classical batik. The philosophy of life contained in the Kawung batik motifs and aesthetics related to the form and process of making Kawung batik are the basis for developing the idea of creating a painting. In addition to studying and examining philosophical values in the Kawung motif, through this study, in-depth observations were also made on the process of making Kawung batik. This is done to find out and understand the application of manufacturing techniques and the medium used. In observing the process of making classical batik, it was found interesting things that in every stage of making the majority of batik done by women. This is reasonable because women, in general, have a gentle, conscientious and patient nature so that batik can produce detailed and subtle forms of ornamentation. The female workers have high dedication, even many elderly mothers who remain faithful to undergo their profession as batik. From this it can be interpreted that the process of making classical batik is complicated, behind it there is a spirit of struggle, participation, and dedication. Departing from the observations of the batik process, the idea to create a female figure as the main symbol in the batik painting work that will be created.

Understanding Javanese women can be seen from the terms used to refer to women, namely Wadon, Wanita, Estri, and Putri who philosophically have noble meanings. The Wadon comes from the Kawi language (Old Javanese) $W a d u$ which means servant, so in this term, it means that women are natural servants of men. The woman is formed from two Javanese words (Kerata Basa) Wani which means brave and Tata which means regular. This base has two different meanings. Wani is arranged which means brave (willing) to be regulated. while Wani Nata, which means to dare to regulate. Thus, the word woman implies that in addition to being able to be regulated by her husband or man also has a role to manage the household, especially in educating their children. Estri comes from the Kawi language: Estren which means Panyurung (pusher). The meaning of this term is that women can be a driver for men. As in the saying that "there are always great women beside great men". Putri, in traditional Javanese civilization, this term is often expressed as an acronym for the words "Putus Tri Perkawis", which refers to the post-re-
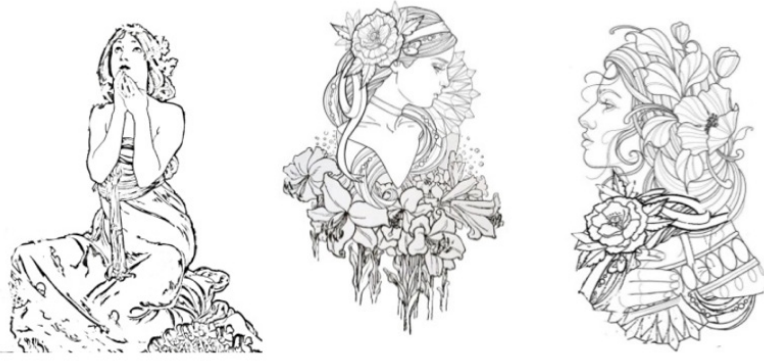

Figure 2. This sketch is inspired by the philosophical meaning of the Kawung batik motif which contains the meaning of controlling lust, respecting nature, and always remembering God

tirement of a woman in her position as a princess. Putri is required to realize three obligations (tri-marriage), both their position as Wadon, Wanita, and Estri.

The philosophical meaning of Javanese women who have obligations as sincere servants are willing to be regulated, directed, also have the responsibility to regulate, to be a driver, shows the logical condition that many classical batiks come from among women. This is interesting than to be associated with philosophical meanings in classical batik as ideas/ideas of art creation, both related to the concept of the theme and the concept of form.

\section{b. The Embodiment of the Idea of Art Creation}

The embodiment of the idea of art creation is done by making sketch designs based on the source of ideas from philosophical meanings, visual aesthetics, and the process of making classical batik motifs Kawung. The approach in sketching is carried out in two ways, namely: 1) considering the aesthetics of the symbols in the Kawung batik motif, and 2) exploring new symbols that are still in harmony with the philosophical values of the Kawung batik. This is done so that the value of the Kawung batik character is still visible in contemporary paintings created. The themes embodied in the sketch include noble values of perfection and purity.

The main symbol embodied in the design sketches is the figure of a woman. Philosophically to represent noble values contained in Kawung motifs. While supporting symbols are taken and or developed from forms of classical batik motifs. The following are sketch forms originating from several Kawung batik motifs.

\section{Creation of Batik Painting}

In the process of forming this work of art using techniques and a medium for making classical batik combined with painting techniques with brushstroke techniques. The steps include:

a. Prepare materials and tools for batik, such as Mori cloth (Primisima), wax, Canting, brushes, pans, and stoves.

b. Mori cloth stretched on a stretcher then drawn according to the sketch that has been selected.

c. A liquid wax that is heated on the stove. 

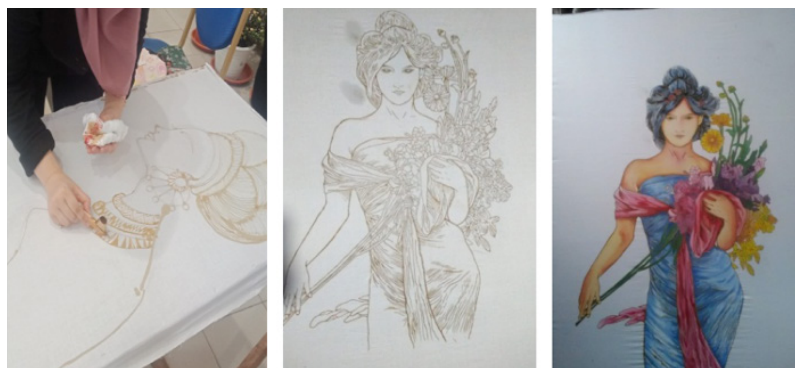

Figure 3. Pouring the wax into a sketch using a Canting (left), Sketches has been covered with wax (central), has been colored with the colet technique (right).

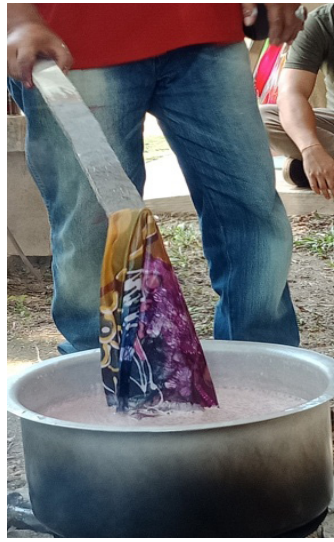

Figure 4. The process of removing wax in boiling water

d. The wax liquid is slowly taken with a Canting and then poured in a sketch on the cloth until it penetrates into the back of the fabric.

e. The next step that must be done is to choose a color to color the motif on batik. The type of dye used is remasol. This type of remasol dye has bright color properties and is easy to use because it is sufficiently mixed with cold water.

f. The coloring process is done by dipping the brush in Remasol dye, then painted on fabric. This coloring technique using a brush is often called the Colet technique.

g. The next process is to lock the color with soaking batik cloth using waterglass liquid so that the color does not fade easily. Waterglass liquid is poured into a bucket sufficient to soak a cloth that has been painted. To get maximum results, this process awaited overnight. After that, the fabric rinsed with clean water and drained in a shady place.

h. The final step in making this batik painting is removing the wax from the fabric by boiling the cloth in boiling water mixed with caustic soda. When boiled, the fabric is stirred to make it easier for the wax to come off the fabric. After the cloth is clean from the remnants of wax, then rinsed and dried in the sun.

4. Artworks Produced

In this article, three batik painting is described through the above process. Each work is described from its visual

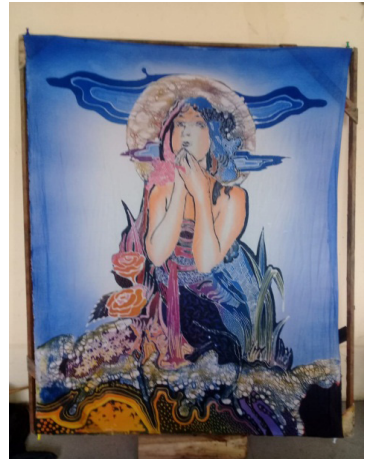

Figure 5. Pray, $90 \times 75 \mathrm{~cm}$, Batik Painting on Fabric

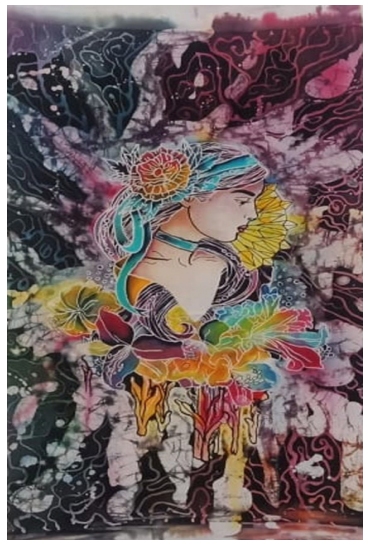

Figure 6. Reflection, 100 x $50 \mathrm{~cm}$, Batik Painting on Fabric

aspect, including the shape of the main icon, supporting icons, and the colors used. The interpretation of the meaning of the resulting artwork is in accordance with contemporary icons chosen to represent the philosophical meaning of the Kawung batik motif.

The batik painting titled 'Pray' is inspired by the philosophical meaning of the Kawung batik motif. The main object in this painting is a woman who is sitting with both hands looking up like she is praying. The position of his face looked up with sharp eyes. Supporting objects in the form of the moon and clouds in the background, roses, creepers, leaves, stones located in the foreground.

The position of the face of a woman who looks up with her hands up represents an activity of praying and asking God for guidance. The filler ornament and the crack effect placed on the front and bottom of the main object represent the top of the mountain. The embodiment of the form of flowers and plants that grow on the top of the mountain means beauty and strength, while the shape of the moon and clouds as a symbol of greatness. In general, this work of art implies the servitude of humans to God, so that they are always given instructions in living life. This is in line with the philosophical meaning of Kawung batik motifs which means controlling lust and always remembering God.

This batik painting entitled 'Reflection' is inspired by the philosophical meaning of the Kawung batik motif. The for- 


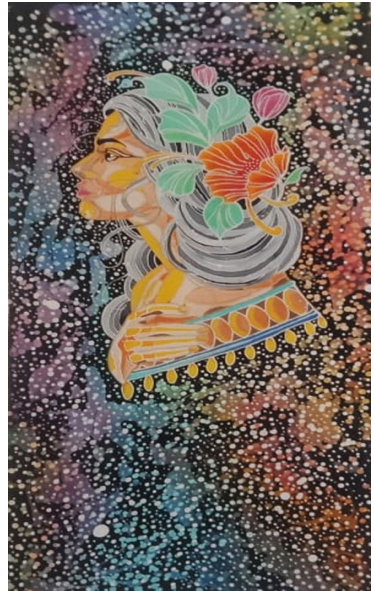

Figure 7. Staring, 80 x $50 \mathrm{~cm}$, Batik Painting on Fabric

mal aspect of this work of art consists of the main icon of a half-body female figure complete with clothes, jewelry, and a crown of roses on her head. The position of his head was looking down with his eyes open. On the body is decorated with a variety of colorful flowers. The supporting objects are clouds-like shapes placed on the background. The colors in this artwork are dominated by brown and purple in the background. While the complementary colors are red, yellow, blue, green, orange in the forms of flowers that adorn the body. The head icon that bows with blank eyes represent an attitude of contemplation to control lust. While the dark color on the background represents a calm inner atmosphere. In general, the idea of creating artwork is in harmony with the philosophical meaning of the Kawung batik motif, about self-reflection to always remember God and control worldly desires.

The idea of creating a painting titled 'Staring' is derived from the philosophical meaning of the Kawung batik motif, which is respect for nature. The main icon in this painting is a figure of a half-body woman with a hand in the chest. The hair is adorned with large flower petals, stems, and leaves. Her face is straight facing forward with sharp eyes. Supporting icons consist of plant shape abstractions and white dots located on the background. The colors in this painting consist of red, blue, green, white and black orange.

The meaning of the main icon represents a reflection and confidence in facing a better life expectancy. This was indicated by the position of the face staring forward and hands held in the chest. While the supporting icons in the form of plant abstractions and white dots on the background represent the dew atmosphere in the morning that teaches humans about the beauty of nature. Dark colors and white dots on the background also represent the nuances of calm that start the day for a beautiful life expectancy in harmony with nature and enlighten the mind. In general, this work of art implies respect for nature which has given life to humans.

\section{CONCLUSIONS}

Based on the results and discussion above, it can be concluded that: 1) the aesthetic values and philosophy of classical batik are potential sources of ideas to be realized in the development of contemporary art, so the meaning of classical batik can be interpreted in various ways. 2) The new icons in the batik paintings produced show the relevance to the philosophical meaning of Kawung batik and the present life situation. Various contemporary painting styles have the opportunity to re-interpret the values in classical batik motifs in various ways. The universality of meaning contained in the Kawung batik motif makes the meaning of the contemporary batik painting produced is still relevant to the current situation.

\section{ACKNOWLEDGEMENTS}

This work was supported by the Directorate of Research and Community Service, the Directorate General of Research and Development Strengthening, Ministry of Research, Technology and Higher Education, Indonesia. For this reason, the authors would like to thank you for providing the applied research grant funds so that the implementation of the research is as targeted.

\section{REFERENCES}

Condronegoro, Mari S. (1995). Busana Adat Keraton Yogyakarta, Makna dan Fungsi dalam Berbagai Upacara. Yayasan Pustaka Nusantara, Yogyakarta.

Budi, Setyo.(2017). Enam Motif Batik Klasik dan Satu Lurik dalam Sistem Nilai Ritual 'Mitoni' Masyarakat Surakarta. Disertasi Doktor, Program Pascasarjana Institut Seni Indonesia Yogyakarta.

Darsono, Sony Kartika. (2007). Budaya Nusantara: Kajian Konsep Mandala dan Konsep Triloka/Bunga terhadap Pohon Hayat Pada Batik. Rekayasa Sains, 2007.

Dallow, Peter. (2003). Representing Creativeness: Practice based Approaches To Research In Creative Arts. Art, Design and Communication In Higher Education. Volume 2, Number 1, 1 March 2003.

Frayling, C. (1997), Practice-Based Doctorates in The Creative and Performing Arts and Design, Coventry: UK Council for Graduate Education.

Kasiyan. (2009). Representasi Tradisi dan Budaya Lokal dalam Seni Rupa Kontemporer Yogyakarta. Imaji: Jurnal Seni dan Pendidikan Seni. Vol.7, No. 2, Agustus 2009 dari https://journal.uny.ac.id/index.php/imaji/article/ view/6632 
Koeswadji K. (1981). Mengenal Seni Batik di Yogyakarta, Proyek Pengembangan Permuseuman. Yogyakarta.

Kushardjanti, Nyi. (2008). Makna Filosofis Motif dan Pola Batik Klasik/ Tradisional, Seminar Nasional Kebangkitan Batik Indonesia. Yogyakarta.

Margolin,V. (1998), 'Design Studies: A Proposal for a New Doctorate', in S. Heller (ed.), The Education of a Graphic Designer, New York: Allworth Press.

Panofsky, Erwin. (1982). Meaning in the Visual Art. Chicago: University of Chicago Press.

Poespowardojo, Soerjanto. (1986). Pengertian Local Genius dan Relevansinya dalam Modernisasi, dalam Ayatrohaedi, (ed.), Kepribadian Budaya Bangsa (Local Genius). Jakarta: Pustaka Jaya.

Poon, Stephen T.F. (2017) The Journey to Revival: Thriving Revolutionary Batik Design and Its Potential in Contemporary Lifestyle and Fashion. International Journal of History and Cultural Studies (IJHCS), Volume 3, Issue 1. Susanto, Sewan. (1980). Seni Kerajinan Batik Indonesia. Departemen Perindustrian RI, Jakarta.

Torwesten, Hans. (1991). Vedanta: Heart of Hinduism. Grove Press, New York. 